\title{
CYP2A13 Gene
}

National Cancer Institute

\section{Source}

National Cancer Institute. CYP2A13 Gene. NCI Thesaurus. Code C117153.

This gene is involved in the oxidation of flavoproteins. 